\title{
Derleme
}

\section{Teriparatid [paratiroid hormon (1-34)] ve diş hekimliği}

\author{
Aydın Keskinrüzgar, ${ }^{1 *}$ Saim Yanık, ${ }^{2}$ \\ Mutan Hamdi Aras, ${ }^{2}$ Sedat Çetiner ${ }^{3}$ \\ ${ }^{1} A g ̆ ı z$, Diş ve Çene Cerrahisi Anabilim Dalı, \\ Adıyaman Üniversitesi Diş Hekimliği Fakültesi, Adıyaman, \\ ${ }^{2}$ Ağız, Diş ve Çene Cerrahisi Anabilim Dalı, \\ Gaziantep Üniversitesi Diş Hekimliği Fakültesi, Gaziantep, \\ ${ }^{3}$ Ağız, Diş ve Çene Cerrahisi Anabilim Dalı, \\ Gazi Üniversitesi Diş Hekimliği Fakültesi, Ankara, Türkiye
}

\section{ÖZET}

Teriparatid kemik kalitesini ve kemik yoğunluğunu arttırmak amacıyla paratiroid hormunundan elde edilen yeni bir ajandır. Paratiroid hormon, kalsiyum ve fosfat metabolizmasını düzenleyererek kemik yapımından sorumlu tutulmaktadır. Teriparatidin osteoporoz hastalarında antirezorptif ajanlara alternatif bir tedavi olması güncel bir konudur. Kemik mineral dansitesinin düşük veya kemik kitlesinin kalitesiz olduğu durumlarda kemik yıkımını engelleyen bu ajanın diğer antirezorptif ajanlardan farklı olarak kemik üzerindeki anabolik etkisi belirtilmiştir. Teriparatidin mekanizmasında, osteoklastlar uyarılarak kemik yıkımının başlatıldığı, diğer bir taraftan ise osteoblastların uyarıldığı belirtilmiştir. Teriparatidin bu özelliği bazı araştırmacıları bu ajanı osteoporoz dışındaki bifosfonat ile ilişkili osteonekroz vakalarında ve periodontal kemik defektlerinde kullanmaya yöneltmiştir. Yapılan araştırmalarda teriparatidin klinik olarak ciddi bir yan etkisinin rapor edilmemesine rağmen kemik üzerindeki anabolik etkisinden dolayı osteosarkom riski vurgulanmıştır. Buna karşın, yapılan klinik araştırmalarda böyle bir durum bildirilmemiştir. Literatürde, yeni bir ajan olan teriparatid ile ilgili az sayıda vaka mevcuttur. Bu ilacın uzun dönem etkilerini belirleyebilmek için bu konuda daha çok prospektif randomize çalışmalara intiyaç vardır.

Anahtar Kelimeler: Çenenin bifosfonat ilişkili osteonekrozu; osteoporoz; paratiroid hormonu; teriparatid

KaynaK Göstermek İçin: Keskinrüzgar A, Yanık S, Aras MH, Çetiner S. Teriparatid [paratiroid hormon (1-34)] ve diş hekimliği. Acta Odontol Turc 2015;32(3):165-70.

YAYıN HAKKI: @ 2015 Keskinrüzgar ve ark. Bu eserin yayın hakkı Creative Commons Attribution License ile ruhsatlandırılmıştır. Kısıtsız kullanım, dağıtım ve her türlü ortamda çoğaltım, yazarlar ve kaynağın belirtilmesi kaydıyla serbesttir.

[Abstract in English is at the end of the manuscript]

Makale gönderiliş tarihi: 22 Kasım .2013; Yayına kabul tarihi: 20 Şubat 2014 *iletișim: Aydın Keskinrüzgar, Ağız, Diş ve Çene Cerrahisi Anabilim Dalı, Adıyaman Üniversitesi Diş Hekimliği Fakültesi, Atatürk Bulvarı, 02200, Merkez, Adıyaman, Türkiye; e-posta: aydink.ruzgar@gmail.com

\section{Giriş}

Teriparatid kemik yapımını ve kemik yoğunluğunu arttırmak, aynı zamanda kemik fraktürlerini azaltmak için paratiroid hormonundan (PTH) elde edilmiştir. ${ }^{1}$ Insan paratiroid hormonu (PTH 1-84) 84 amino asit bulunan zincirden oluşmaktadır. Teriparatid 2002 yılında Eli Lilly (Indianapolis, IN, ABD) tarafından geliştirilen, PTH'nin ilk 34 amino asitinden (PTH 1-34) oluşan bir rekombinant insan proteinidir. Bu ajan, Escherichia coli türünden DNA rekombinant teknolojisiyle üretilmiştir. ${ }^{2}$

PTH'nin ana görevi kemikte kalsiyum ve fosfat metabolizmasını düzenlemektir. Bu hormon osteoklastları uyararak kemik yapım mekanizmasını harekete geçirir ve bu uyarılma ile kemik yıkımı başlarken, diğer taraftan ise osteoblastik aktivite başlar. Bunun sonuncu yeni kemik yapımı gerçekleşir. PTH'nin sürekli uyarılması ise ileri derecede kemik yıkımına sebep olup, bu yüzden aralıklı PTH salınımı ile kemik yapımı kontrol edilir. ${ }^{3}$

Dolaşımdaki serum kalsiyum düzeylerindeki herhangi bir azalma reseptörler aracılığıyla paratiroid bezini uyarır ve PTH salınımını artırır. PTH osteoklastik aktiviteyi uyarır, renal tubüllerde kalsiyum geri emilimini artırır, bu durum aynı zamanda renal fosfat kaybına da neden olur. ${ }^{4}$ Dolaylı yoldan ise 1-alfa-hidroksilaz enziminin uyarılmasıyla 1.25 dihidroksi vitamin D artışını sağlayıp bağırsakta kalsiyum ve fosfat emilimini arttırır. ${ }^{5}$ Tüm bu etkiler PTH'nin kalsiyum metabolizmasının düzenlenmesinden sorumlu olduğunu kanıtlar niteliktedir.

Teriparatidin genel metabolizmasının ve atılımının tamamen açıklanamamasına karşın, PTH'nin periferal metabolizması karaciğerde spesifik olmayan enzimatik mekanizma ile gerçekleştiği ve bunu takiben atılımı ise böbrekler aracılığıyla gerçekleştiği düşünülmektedir. Teriparatid subkutan enjeksiyon ile daha yaygın absorbe edilir ve biyoyararlanım yaklaşık \%95'tir. ${ }^{3}$ Enjeksiyondan sonra serumdaki en yüksek konsantrasyon değerine otuzuncu dakikalarda ulaşır. ${ }^{6}$ Teriparatidin yarılanma ömrü yaklaşık 1 saat olup yaklaşık 3 saat sonra konsantrasyonunda önemli azalmalar olur. ${ }^{7}$ Teriparatid uygulandıktan sonra serum kalsiyum seviyesi ise yaklaşık 2 saat sonra artmaya başlar, altıncı saatten sonra seviye azalır, en düşük seviyeler ise 16-24. saatlerdedir. ${ }^{8}$ 
Teriparatid, son zamanlarda osteoporoz tedavisinde antirezorptif bir ajan olarak kullanılmaktadır. Ayrıca teriparatidin bifosfonatla ilişkili osteonekroz vakalarında kulIanılması ile ilgili birkaç vakanın ve laboratuvar çalışmalarının bulunduğu bildirilmiştir. ${ }^{9,10}$ Bu derlemenin amacı teriparatidin klinik kullanım alanları, biyokimyasal etkileri, dozu ve ilaç etkileşimleri ve yan etkileri hakkında güncel bilgileri gözden geçirmektir.

\section{Klinik kullanım alanları}

\section{Osteoporoz tedavisindeki kullanımı}

Osteoporoz, kemik kitlesinin kaybı ve frajilite ile karakterizedir. Osteoporoz patogenezinde, yeni kemik oluşumunda başarısızık olduğu bilinmektedir. Osteoporoz hastalarında kemik yoğunluğunun ve kalitesinin azalmasından dolayı minimal travmalar sonucu veya spontan oluşan kırıklar meydana gelmektedir. Osteoporoz tedavisinde kullanılan ilaçların amacı kemik mineral dansitesini (KMD) arttırarak kemiği daha dirençli hale getirmektir. Antirezorptif olarak kullanılan bu ilaçlar genellikle kalsiyum, östrojen, bifosfonat ve kalsitonindir. ${ }^{9}$

Teriparatid, son zamanlarda dünyada ve ülkemizde osteoporoz tedavisinde yer alan antirezorptif bir ajan olarak kullanılmaktadır. ${ }^{11}$ Osteoporoz tedavisinde kullanılan antirezorptif ajanlar ile teriparatid bazı araştırmacılar tarafından karşılaştııılmıştır. Body ve ark. ${ }^{12}$ menopoz sonrası osteoporoz teşhisi olan kadınlarda bir bifosfonat olan alendronatın ve teriparatidin etkisini vertebral olmayan fraktür sıklığında karşılaştırmıştır. Osteoporozlu kadınlara subkutan enjeksiyon yoluyla günlük olarak $40 \mu \mathrm{g}$ teriparatid veya ağızdan $10 \mathrm{mg}$ alendronat verilmiştir. Tedavi sonrasında lumbar spinalarda KMD oranlarındaki artış, teriparatid kullananlarda $\% 12.2$ ve alendronat kullananlarda \%5.6 olarak belirtilmiştir. Ayrıca teriparatidin femoral boyun bölgesinde KMD'yi arttırmakla birlikte genel vücut KMD'sinde de alendronattan daha üstün olduğu vurgulanmıştır. Sonuç olarak bu çalışmada vertebral olmayan fraktür oluşma riski teriparatid kullananlarda alendronat kullananlardan daha düşük bulunmuş̧ur.

Horwitz ve ark. ${ }^{13} 3$ ay boyunca yüksek dozda kullanılan PTH'yi (günlük olarak subkutan uygulanan $40 \mu \mathrm{g}$ teriparatid) güçlü bir anabolik ajan olarak gözlemlemiş ve bu ilacın lumbar spinaların KMD'sinde \%4.7'lik bir artış gösterdiğini belirtmiştir. Ayrıca yüksek dozda kullanılmasına rağmen rahat tolere edilebilen bir ilaç olduğu vurgulanmıştır.

Kurland ve ark. ${ }^{14}$ osteoporozlu erkeklerde PTH'nin iskelet sistemi tamirinde güçlü bir etken olduğunu bildirmişlerdir. Ayrıca bu ilacın lumbar spinalarda ve kalça ekleminde KMD'yi yükselttiği ve aynı zamanda anabolik etkisinin olduğu vurgulanmıştır.
Neer ve ark. ${ }^{8}$ osteoporozun tedavisinde subkutan olarak 20 veya $40 \mu \mathrm{g}$ dozlarda uygulanan PTH'nin vertebral ve vertebral olmayan kırık riskini azalttığını, vertebral, femoral ve total vücut KMD’lerini arttırdığını ve bu ilacın rahat tolere edildiğini bildirmişlerdir.

Rittmaster ve ark. ${ }^{15}$ tarafından bir yıl boyunca subkutan olarak uygulanan PTH $(50 \mu \mathrm{g}, 75 \mu \mathrm{g}$ ve $100 \mu \mathrm{g})$ ve alendronatı birlikte kullanan osteoporozlu hastalarda, vertebralarda KMD'nin artışının yalnız başına yapılan alendronat veya östrojen tedavisinden daha önemli düzeyde olduğu vurgulanmıştır. Bu durumda da PTH'nin kombine edilmesinin vertebral osteoporozlu hastalarda KMD'ye olumlu katkıda bulunduğu gösterilmiştir.

Finkelstein ve ark. ${ }^{16}$ tarafından kadınlardan oluşan bir hasta grubuna intranazal olarak nafarelin (gonadotropin serbestleştirici hormon $(\mathrm{GnRH})$; analog nafarelin asetat) diğer gruba ise günlük olarak $40 \mu \mathrm{g}$ PTH (1-34) ve nafarelin birlikte verilmiştir. Sadece nafarelin alanlarda anterior-posterior spinalarda, lateral spinalarda, femoral boyunda, trokanterde ve total vücutta KMD değerleri kontrol verileri ile karşılaştıııldığında sırasıyla $\% 4.9, \% 4.9, \% 4.7, \% 4.3$ ve \%2.0 daha az bulunmuştur. Kombine edilen grupta ise KMD'de azalmanın aksine anterior-posterior spinalarda \%2.1 ve lateral spinalarda \%7.5 artış olmuştur. Ayrıca kombine grupta şiddetli östrojen eksikliğine rağmen femoral, trokanter ve total vücutta KMD değerleri korunmuştur.

Yapılan bu araştırmalara göre osteoporoz tedavisinde kullanılan teriparatid genellikle günlük olarak 20 $\mu \mathrm{g}$ ve $40 \mu \mathrm{g}$ dozlarda subkutan olarak uygulanmıştır. Tedavi süresi de yaklaşık olarak 6-24 ay sürmektedir. Teriparatid diğer ilaçlarla birlikte kullanıldığında ise KMD'yi daha etkin şekilde arttırdığı belirtilmiş̧ir. Teriparatidin maliyet açısından diğer antirezorptif ajanlara göre yaklaşık sekiz kat daha pahalı bir tedavi şekli olduğu belirtilmiştir. ${ }^{3} \mathrm{Bu}$ nedenle osteoporozlu hastalar teriparatid kullanımına göre daha ucuz ilaçları tercih edebilmektedir.

Sonuç olarak osteoporozlu hastalarda teriparatidin, diğer tedaviler ile karşılaştırıldığında KMD ve kemik sağlamlığını daha etkin şekilde artırdığı, ayrıca kemik tamirine de yardımcı olduğu belirtilmiştir.

\section{Bifosfonat ile ilişkili osteonekroz tedavisinde kullanımı}

Bifosfonat metastatik kanserlerde, osteoporoz ve Paget hastalığında kullanılan bir ilaç türüdür. ${ }^{17}$ Bifosfonat kullanan hastalarda osteonekroz oluşumu ciddi bir komplikasyon olarak rapor edilmiş olup ilk vaka 2003 yılında Marx tarafından bildirilmiştir. ${ }^{18}$ Son dönemlerde ise bifosfonat kullanımına bağlı ortaya çıkan osteonekroz görülme insidansı giderek artmaktadır. Bu osteonekroz alanları zaman zaman iliak kemik, femur başı gibi bölgelerde çok nadiren de olsa ortaya çıksa bile en sık gö- 
rüldüğü bölge çenelerdir. Bu durumun ortaya çıkmasında kemik yapım ve yıkım olaylarının düşük olması, kan akımının azalması, kemik hücrelerinin nekrozu ve apoptozis gibi çeşitli mekanizmaların rol oynadığı düşünülmektedir. Hücresel düzeyde osteoklastları inaktive ederek kemik yıkımını engellediği ve bunun sonucu osteoblastların da kemik yapımını durdurarak kemik yapım-yıkım mekanizmasının bozulduğu savunulmuştur. ${ }^{19}$ Ayrica periodontal enfeksiyon ve protez irritasyonunu bile içeren travmanın osteonekroz meydana gelme riskini arttırmasına rağmen spontan olarak da gelişebileceği belirtilmiştir. ${ }^{20}$

Bifosfonat ile ilişklili osteonekroz tedavisinde birçok tedavi şekli uygulanmıştır. Bunların antibiyotikler, analjezikler, iyi bir oral hijyen, ağız gargaraları ve yüzeysel debridman temizlikleri gibi konservatif yaklaşımlar olmasına karşın bu tedavi şekillerinde ideal bir başarı sağlanamayabilmektedir. ${ }^{21-23}$

Cerrahi olarak rezeksiyon, sert ve yumuşak doku greftleri ile rekonstrüksiyon yapılmasına rağmen osteonekroz alanlarının daha fazla şiddetlendiği rapor edilmiştir. ${ }^{24}$ Bazı araştırmacılar hiperbarik oksijen tedavisinin (HPO) başarılı olduğunu belirtmelerine rağmen bazı araştırmacılar ise HPO'nun başarı sağlamadığını belirtmiştir. ${ }^{25-28}$

Teriparatidin, bifosfonatın aksine osteoklastların aktivasyonunu bozmadan kemik yapım-yıkım olaylarını sağlayarak sağlıklı kemik oluşumuna katkısı olacağını düşünülmektedir. Ayrıca bu ilaç, osteoporoz hastalarında kemik yapımındaki olumlu etkilerinden dolayı da bazı araştırmacılar tarafından bifosfonat ile ilişkili osteonekroz vakalarında kullanılmıştır. ${ }^{9}$

Ma ve ark. ${ }^{29}$ yaptığı bir çalışmada overektomi yapılmış ratlarda alendronat uygulanmış ve sonrasında tibialarında kemik yapımının baskılandığı belirtilmiştir. Bu çalışmadaki ratlara 2 aylık teriparatid $(30 \mu \mathrm{g} / \mathrm{kg})$ uygulaması sonrasında tibialarındaki kemik yapımının arttığı belirtilmiştir

Cheung ve ark. ${ }^{30}$ geçmişte kalça kırığı hikayesi nedeniyle haftalık $70 \mathrm{mg}$ alendronat, günlük olarak kalsiyum karbonat $(1500 \mathrm{mg})$ ve kolekalsiferol $(25 \mu \mathrm{g})$ alan bir hastada, diş çekimi sonrasında sol alt çene bölgesinde osteonekroz oluştuğunu tespit etmiştir. Bifosfonat ile ilişkili olan bu osteonekroz vakasında hastadan onam formu alarak hastaya subkutan olarak teriparatid (günlük $20 \mu \mathrm{g}$ ) uygulanmış ve 8 . hafta sonunda osteonekroz alanın tamamen iyileştiğini klinik olarak gözlemlemiştir.

Arthur ve ark. ${ }^{31}$ hikayesinde zoledronik asit kullanan 56 yaşında kadın bir hastanın sağ alt çenesinde oluşan osteonekroza karşı birçok tedavi yöntemine rağmen olumlu bir sonuç alamamıştır. Son olarak 18 aylık teriparatid (subkutan olarak günlük $20 \mu \mathrm{g}$ ) tedavisine başlanmış ve bu tedavinin üçüncü ayında alt çenedeki nekroz alanlar iyileşmeye ve şikayetler gerilemeye başlamıştır. Onsekizinci ayın sonunda osteonekrozun tamamen iyileştiği bildirilmektedir.

Harper ve ark. ${ }^{32}$ alendronat kullanımı ile ilişkili sol alt çene myleoid bölgede oluşan osteonekroz vakasında 2 yıl teriparatid (subkutan olarak günlük $20 \mu \mathrm{g}$ ) tedavisi uygulamıştır. Onuncu ayda oral mukozanın sağlıklı hale geldiği ve panoramik görüntüde kemik oluşumu belirtilmiştir.

Lee ve ark. ${ }^{19} 78$ yaşında alendronat ile ilişkili alt çenede lokalize olmuş osteonekroz vakasında antibiyotik, antibakteriyal ağız gargarası verilmiş ve minör cerrahi ile debridman yapmıştır. Bundan sonra hastaya günlük olarak $20 \mu \mathrm{g}$ teriparatid (subkutan enjeksiyon) 7 ay boyunca uygulanmıştır. Teriparatid uygulanmasının 4. haftasında ağız mukozasının iyileştiği ve ağrıların azaldığı belirtilmiştir. Altıncı ayda ise kemik rejenerasyonunun olduğu belirlenmiştir.

Bashutski ve ark. ${ }^{33}$ yaptığı bir klinik çalışmada şiddetli periodontal hastalığı bulunan 40 hasta iki gruba ayrılarak, birinci gruptaki 20 hastaya 6 hafta boyunca günlük $20 \mu \mathrm{g}$ teriparatid (subkutan enjeksiyon) ve bunun yanında 1000 mg kalsiyum ve 800 IU kolekalsiferol verilmiştir. İkinci gruptaki 20 hasta plasebo grubu olarak ayarlanmış ve bu gruptaki hastalar da kalsiyum ve vitamin D almıştır. Her iki gruptaki hastalara periodontal cerrahi ile debritman yapıldıktan 12 ay sonra periodontal kemikteki iyileşme radyografik olarak incelenmiştir. Periodontal kemik seviyesinde teriparatid ile tedavi edilen grupta \%29 artış, plasebo grubunda ise \%3 artış tespit edilmiştir. Ayrıca klinik olarak da teriparatid kullananlarda periodontal cep derinliğinde azalma ve klinik ataşman seviyesinde artış belirlenmiştir. Bu durumda da teriparatidin periodontal kemik defektlerinde yeni kemik oluşumuna katkısının olduğu vurgulanmıştır. Bifosfonat kullanan hastalarda çene kemiklerinin dişler aracığıyla ağız ortamına doğrudan açılması nedeniyle osteonekroz oluşmasına zemin hazırladığı belirtilmiştir. Bu hastalarda peirodontal hastalıkların eşlik etmesiyle bifosfonatla ilişkili osteonekrozların oluşma riski artmaktadır. Teriparatidin periodontal dokuların sağlıklı kalmasınında rol oynadığı yapılan bu çalışmada belirtilmiştir.

Yapılan bu araştırmalara göre bifosfonat ile ilişkili osteonekroz vakalarında teriparatid kullanımı sonrasında osteonekrozun iyileştiği belirtilmiştir. Osteonekroz vakalarında teriparatid kullanımında genellikle günlük olarak $20 \mu \mathrm{g}$ dozda subkutan olarak uygulanmıştır. Tedavi süresi ise 2 ile 24 ay arasında değişmektedir.

Bifosfonat ile ilişkili osteonekroz vakalarında teriparatid kullanımı çok yeni bir tedavi şekli olmakla birlikte araştırmalar sınırlı sayıda bulunmaktadır. Ayrıca bu tür osteonekroz vakalarında şimdiye kadar herhangi bir tedavi protokolünün oluşmamasından dolayı teriparatid ile ilgili araştırmalar giderek artmaktadır. 


\section{Kemikteki biyokimyasal belirteçler üzerine etkileri}

Teriparatidin kemik yapımında ve yıkımında biyokimyasal belirteçler üzerine etkileri tam açıklanamamıştır. Kemik yapımından sorumlu belirteçler; kemik serum alkalin fosfataz (BSAP; kemik serum alkalen fosfataz), osteokalsin (OC; osteokalsin), karboksiterminal propeptit tip 1 prokollajen (P1CP) ve amino terminal ekstensiyon peptid prokollajen tip 1 (P1NP) olarak rapor edilmiştir. Kemik rezorpsiyonundan sorumlu belirteçler ise üriner deoksipiridinolin kreatinin oranı (DPD), üriner tip 1 kollajen ile çapraz bağlı C-telopeptid kreatinin oranı (CTX) ve üriner tip 1 kollajene çapraz bağlı N-telopeptid (NTX) olarak belirtilmiştir (Tablo 1). ${ }^{9}$

Miyauchi ve ark. ${ }^{34}$ yaptığı bir çalışmada, teriparatidin osteoporozlu kadınlarda kemik belirteçleri üzerine etkileri araştırı ış̧tır. Bu çalışmada 3 ayrı teriparatid dozu $(10 \mu \mathrm{g}, 20 \mu \mathrm{g}$ ve $40 \mu \mathrm{g})$ uygulanmıştır. Her üç doz tedavide dördüncü hafta P1CP seviyesi en yüksek değerlere ulaştığı belirtilmiştir. Altıncı ayda bu değerlerin $10 \mu \mathrm{g}$ verilen grupta başlangıç değerlerinin altına düştüğü, $20 \mu \mathrm{g}$ verilen grupta başlangıç değerlerine benzer olduğu ve $40 \mu \mathrm{g}$ verilen grupta ise başlangıç değerlerinin üzerinde olduğu belirtilmiştir. P1NP seviyesi dördüncü haftada 3 grupta da en yüksek değerlerde ölçülmüştür. Altıncı ayda bu değerlerin $10 \mu \mathrm{g}$ verilen grupta başlangıç değerlerine benzer olduğu, 20 ve 40 $\mu \mathrm{g}$ verilen gruplarda ise başlangıç değerlerinin üzerinde olduğu belirtilmiştir. BSAP seviyesinin ise altıncı ayda 20 ve $40 \mu \mathrm{g}$ verilen gruplarda başlangıç değerlerinin üzerindedir. Üriner CTX seviyesi $40 \mu \mathrm{g}$ verilen grupta üçüncü ayda en yüksek değerlere ulaştığı, altıncı ayda da başlangıca göre yüksek değerlerde olduğu, $20 \mu \mathrm{g}$ verilen grupta ise en yüksek değerlere altıncı ayda ulaşıdığı bildirilmiştir.

Sethi ve ark. ${ }^{35}$ tarafından osteoporozlu hastalarda teriparatidin plaseboya göre kemik yapım belirteçlerinden BSAP ve OC'yi yükselttiği, kemik yıkım belirteçlerinden ise sadece üriner DPD'yi yükselttiği rapor edilmiştir.

Body ve ark..$^{12}$ teriparatid veya alendronat tedavisi gören osteoporozlu kadınlarda, teriparatid tedavisi alanlarda üriner NTX değerlerinin daha yüksek olduğunu, alendronat alanlarda ise kemik yapımının (serum BSAP) ve yıkımının (üriner NTX) baskılandığı belirtilmiştir. Anastasilakis ve ark. ${ }^{36}$ risedronat tedavisi alanlarda te- riparatid alanlara göre serum P1NP, CTX ve total ALP değerlerinin önemli ölçüde azaldığını vurgulamaktadır.

$\mathrm{Bu}$ araşıırmalara göre teriparatidin kemik yapım ve yıkım belirteçlerinin seviyesini arttırdığı anlaşılmaktadır. Bu etki de kemik tamir olayını harekete geçirerek yeni kemik oluşumunu sağlamaktadır.

\section{Doz ve ilaç etkileşimi}

Teriparatidin tavsiye edilen dozu subkutan yolla günlük $20 \mu$ g'dir. Kullanım süresi 2 yılı aşmamalıdır. Teriparatidin $750 \mu \mathrm{g} / 3 \mathrm{ml}$ enjeksiyonluk solüsyon içeren kullanıma hazır kalem şeklinde pazarlanmakta olup bu enjeksiyon 28 gün süresince kullanılır. İlacın güvenirliği ve etkinliği ile ilgili uzun dönem çalışma bulunmamaktadır. ${ }^{3}$

Okimoto ve ark. ${ }^{37}$ haftalık enjeksiyon yapılan PTH'nin hem kortikal hemde trabeküler kemiğin yapımını uyardığını, kemik yapısında ve kemik iliğinde olumlu etkileri olduğunu rapor etmiş̧lerdir. Kneissel ve ark. ${ }^{38}$ uzun dönem aralıklı olarak yapılan PTH tedavisinin sağlıklı yeni kemik oluşumunu sağladığını göstermiş olup bu iki araştırmacı günlük PTH kullanımı yerine aralıklı kullanımı tercih etmiş̧ir.

Sağlıkı 20 insanda $25 \mathrm{mg}$ hidroklorotiazid ve $40 \mu \mathrm{g}$ teriparatid kullanılanılan bir araştırmada bu iki ilacın etkileşiminde serum kalsiyum seviyesinde önemli bir değişiklik tespit edilmemiştir. Üriner kalsiyum atıımının ise 24 saat sonunda önemsiz miktarda olduğu görülmüştür. ${ }^{1}$

Yapılan diğer bir araştırmada ise 9 sağlıklı insana ve 17 böbrek yetersizliği olan hastaya uygulanan i.v. furosemid $(20-100 \mathrm{mg}$ ) ile $40 \mu \mathrm{g}$ teriparatidin etkileşiminde serum kalsiyum seviyesinde $\% 2$ lik bir yükselme olmuştur. Ayrıca 24 saat boyunca üriner kalsiyum değerinde klinik olarak önemli bir değişiklik bildirilmemiştir. ${ }^{1}$

Günlük olarak digoksin alan 15 sağlıkı insana tek doz teriparadit uygulanmış ve sistolik zaman aralığında bir değişim olmadığı belirtilmişsir. Teriparatidin nadir de olsa dijital toksisitesi olan hastalarda hiperkalsemiye neden olduğu araştıııılar tarafından savunulmuştur. Bu durumda da teriparatid geçici olarak serum kalsiyum seviyesini yükselttiği için; dijital grubu kalp ilacı alan hastalarda dikkatli kullanılmalıdır. ${ }^{3}$

Teriparatidin diğer ilaçlarla etkileşimi ilgili ciddi bir rapor belirtilmemesine rağmen yeni bu ilacın güvenilirliği ve ilaç etkileşimleri ilgili yeterli çalışma bulunmamaktadır.

Tablo 1. Kemik yapım ve yıkım belirteçleri

\begin{tabular}{ll}
\hline Kemik yapımından sorumlu belirteçler & Kemik yıkımından sorumlu belirteçler \\
\hline Kemik serum alkalen fosfataz (BSAP) & Üriner deoksipridinolin kreatinin oranı (DPD) \\
Osteokalsin (OC) & Üriner tip 1 kollajen ile çapraz bağı C-telopeptit kreatinin oranı (CTX) \\
Karboksiterminal propeptid tip 1 prokollajen (P1CP) & Üriner tip 1 kollajene çapraz bağı N-telopeptit (NTX) \\
\hline Amino terminal ekstensiyon peptid prokollajen (P1NP) & \\
\hline
\end{tabular}




\section{Yan etkileri}

Teriparatidin yan etkileri tam belirlenmemekle birlikte baş ve boyun ağrısı, halsizlik, senkop, bulantı, kabızlık, baş dönmesi, depresyon, uykusuzluk, hipertansiyon, anjina pektoris, hiperürisemi ve hiperkalsemidir. Kullanılan doz yükseldikçe yan etkilerin ortaya çıkma riskinin artabileceği belirtilmiştir. ${ }^{9}$

Teriparatidin üzerinde durulması gereken en önemli yan etkisi osteosarkom riskidir. Yapılan deneysel çalışmalarda, ratlarda osteosarkom insidansını arttırdığı belirtilerek, ilacın bu etkisi FDA (Food and Drug Administration) tarafından vurgulanmaktadır. Bu ilacın insanlarda osteosarkom riskini arttırdığı belirsizliğini korurken, hastaların yararına olacağı durumlarda reçete edilmesine gereksinim duyulduğu belirtilmiştir. Ancak Paget hastalığında, herhangi bir sebeple osteosarkom riski taşıyan ve daha önceden radyoterapi gören hastalarda, açıklanamayan nedenlerle kemikte alkalen fosfatazın (ALP) yükselmesi ve epifizin açık olması durumunda reçete edilmemelidir. ${ }^{3}$ Teriparatid kemik yapım yıkım olaylarını arttırdığı için kemiği ilgilendiren metastatik vakalarda da kullanılmaması gerektiği belirtilmiştir. ${ }^{19}$ Bazı araştırmacılara göre ise gebelik, şiddetli böbrek ve karaciğer hastalıklarında reçete edilmemelidir. ${ }^{39,40}$

Neer ve ark. ${ }^{8}$ yaptıkları bir klinik araştırmada teriparatidi $20 \mu \mathrm{g}$ ve $40 \mu \mathrm{g}$ subkutan olarak vermişlerdir. Bu araştırmada 1637 hastanın 94'ünde yan etkiler görüldüğü belirtilmiş; bu hastalarda bulantı, baş ağrısı, baş dönmesi ve bacak krampları bildirilmiştir. Araştırıcılar yüksek dozdaki teriparatid $(40 \mu \mathrm{g})$ alınması sonucu PTH'ye karşı antikor sirkülasyonunda artış belirtmiştir; fakat bu artış sonucu herhangi bir komplikasyon gözlenmemiştir.

Body ve ark. ${ }^{12}$ çalışmalarına göre alendronat alan hastaların \%19.2'sinde; teriparatid alan hastaların \%5.5'inde baş ağrıları rapor edilmiştir. Ayrıca teriparatid kullanımı sonucu 6 hastada bacak krampları rapor edilmiştir. Aynı çalışmada, bir hastada ise teriparitidin enjeksiyonundan sonra serum kalsiyum seviyesi çok yükseldiği için ilacın kesildiği belirtilmiştir. Fakat diğer hastalarda da serum kalsiyum seviyesinin yükselmesi sonucu herhangi bir semptom görülmediği belirtilmiştir.

Miyauchi ve ark. ${ }^{34}$ yaptığı araştırmada ise teriparatid enjeksiyonundan sonra mide bulantısı, egzama, baş ağrısı, kas spazmı ve ürik asitte artma belirtilmiştir. Bulantı ve baş ağrısının, yaygın olarak yüksek doz teriparatid $(40 \mu \mathrm{g})$ kullananlarda görüldüğü belirtilmiştir. Sethi ve arkadaşlarının ${ }^{35}$ yaptığı benzer bir çalışmada ise önemli bir yan etki rapor edilmemiştir.

Yapılan bu araştırmalara göre klinik olarak ciddi bir yan etki rapor edilmemiştir. Ayrıca osteosarkom, teriparatid kullanımında en tehlikeli durum olarak belirtilmesine rağmen yapılan klinik araştırmalarının hiçbirinde osteosarkom vakası rapor edilmemiştir.

\section{SoNUÇ}

Teriparatid osteoporoz tedavisinde alternatif bir tedavi yöntemi olarak gösterilmesine rağmen henüz güvenilirliği ve etkinliği tartışmalı olup maliyeti yüksek bir tedavi yöntemidir. Literatürde, teriparatidin bifosfonat ile ilişkili osteonekrozda az sayıda vakada kullanılmış olduğu görülmekle beraber, bu ilacın uzun dönem etkilerini belirleyebilmek için bu konuda daha çok prospektif randomize çalışmalara intiyaç vardır.

Çıkar çatışması: Yazarlar bu çalışmayla ilgili herhangi bir çıkar çatışmalarının bulunmadığını bildirmişlerdir.

\section{KAYNAKLAR}

1. Forteo $®$ (teriparatid injection) package insert. Indianapolis, IN: Eli Lilly and Company; November 2002.

2. Cosman F. Parathyroid hormone treatment for osteoporosis. Curr Opin Endocrinol Diabetes Obes 2008;15:495-501.

3. Honeywell M, Phillips S, Branch III E, Vo KA, Marks El, Thompson M. Teriparatid for osteoporosis: a clinical review. P\&T 2003;28:713-6.

4. Magno AL, Ward BK, Ratajczak T. The calcium-sensing receptor: a molecular perspective. Endocr Rev 2011;32:3-30.

5. Peacock M. Calcium metabolism in health and disease. Clin J Am Soc Nephrol 2010;1:S23-30.

6. Suzuki Y, Nagase Y, Iga K, Kawase M, Oka M, Yanai S, et al. Prevention of bone loss in ovariectomized rats by pulsatile transdermal iontophoretic administration of human PTH (1-34). J Pharm Sci 2002;91:350-61.

7. Cosman F, Shen V, Herrington B, Lindsay R. Response of the parathyroid gland to infusion of human parathyroid hormone-(1-34) [PTH(1-34)]: demonstration of suppression of endogenous secretion using immunoradiometric intact PTH-(1-84) assay. J Clin Endocrinol Metab 1991;73:1345-51.

8. Neer RM, Arnaud CD, Zanchetta JR, Prince R, Gaich GA, Reginster $J Y$, et al. Effect of parathyroid hormone (1-34) on fractures and bone mineral density in postmenopausal women with osteoporosis. N Engl J Med 2001;344:1434-41.

9. Inderjeeth CA, Chan K, Glendenning P. Teriparatid: its use in the treatment of osteoporosis. Clin Med Insights Ther 2011;3:67-80.

10. Dayisoylu EH, Şenel FÇ, Üngör C, Tosun E, Çankaya M, Ersöz S, et al. The effects of adjunctive parathyroid hormone injection on bisphosphonate-related osteonecrosis of the jaws: an animal study. Int $J$ Oral Maxillofac Surg 2013;42:1475-80.

11. Türkiye Endokrinoloji ve Metabolizma Hastalıkları Derneği, Osteoporoz ve Diğer Metabolik Kemik Hastalıkları Çalışma Grubu. Metabolik Kemik Hastalıkları Tanı ve Tedavi Kılavuzu. 1. Baskı. İstanbul: Özgün Ofset Tic. Ltd. Şti; 2012.

12. Body JJ, Gaich GA, Scheele WH, Kulkarni PM, Miller PD, Peretz A, et al. A randomized, double-blind trial to compare the efficacy of teriparatid [recombinant human parathyroid hormone (1-34)] with alendronate in postmenopausal women with osteoporosis. J Clin Endocrinol Metab 2002;87:4528-35.

13. Horwitz MJ, Tedesco MB, Gundberg C, Garcia-Ocana A, Stewart AF. Short-term, high-dose parathyroid hormone-related protein as a skeletal anabolic agent for the treatment of postmenopausal osteoporosis. J Clin Endocrinol Metab 2003;88:569-75.

14. Kurland ES, Cosman F, McMahon DJ, Rosen CJ, Lindsay R, Bilezikian JP. Parathyroid hormone as a therapy for idiopathic osteoporosis in men. J Clin Endocrinol Metab 2000;85:3069-76.

15. Rittmaster RS, Bolognese M, Ettinger M, Hanley DA, Hodsman AB, Kendler DL, et al. Enhancement of bone mass in osteoporotic women with parathyroid hormone followed by alendronate. J Clin Endocrinol Metab 2000;85:2129-34. 
16. Finkelstein JS, Klibanski A, Arnold AL, Toth TL, Hornstein MD, Neer RM. Prevention of estrogen deficiency related bone loss with human parathyroid hormone (1-34): a randomized controlled trial. JAMA 1998;280:1067-73.

17. Russell RG, Watts NB, Ebetino FH, Rogers MJ. Mechanisms of action of bisphosphonates: similarities and differences and their potential influence on clinical efficacy. Osteoporos Int 2008;19:733-59.

18. Marx RE. Pamidronate (Aredia) and zoledronate (Zometa) induced avascular necrosis of the jaws: a growing epidemic. J Oral Maxillofac Surg 2003;61:1115-7.

19. Lee JJ, Cheng SJ, Jeng JH, Chiang CP, Lau HP, Kok SH. Successful treatment of advanced bisphosphonate-related osteonecrosis of the mandible with adjunctive e therapy. Head Neck 2011;33:1366-71.

20. Biasotto M, Chiandussi S, Zacchigna S, Moimas S, Dore F, Pozzato $\mathrm{G}$, et al. A novel animal model to study non-spontaneous bisphosphonates osteonecrosis of jaw. J Oral Pathol Med 2010;39:390-6.

21. Pazianas M, Miller $P$, Blumentals WA, Bernal M, Kothawala P. A review of the literature on osteonecrosis of the jaw in patients with osteoporosis treated with oral bisphosphonates: prevalence, risk factors, and clinical characteristics. Clin Ther 2007;29:1548-58.

22. Rizzoli R, Burlet N, Cahall D, Delmas PD, Eriksen EF, Felsenberg $\mathrm{D}$, et al. Osteonecrosis of the jaw and bisphosphonate treatment for osteoporosis. Bone 2008;42:841-7.

23. Ruggiero SL, Dodson TB, Assael LA, Landesberg R, Marx RE, Mehrotra B, et al; American Association of Oral and Maxillofacial Surgeons. American Association of Oral and Maxillofacial Surgeons position paper on bisphosphonate related osteonecrosis of the jaws-2009 update. $J$ Oral Maxillofac Surg 2009;67:2-12.

24. Farrugia MC, Summerlin DJ, Krowiak E, Huntley T, Freeman S, Borrowdale $\mathrm{R}$, et al. Osteonecrosis of the mandible or maxilla associated with the use of new generation bisphosphonates. Laryngoscope 2006;116:115-20.

25. Shimura K, Shimazaki C, Taniguchi K, Akamatsu S, Okamoto M, Uchida R, et al. Hyperbaric oxygen in addition to antibiotic therapy is effective for bisphosphonate-induced osteonecrosis of the jaw in a patient with multiple myeloma. Int J Hematol 2006;84:343-5.

26. Freiberger JJ, Padilla-Burgos $\mathrm{R}$, Chhoeu $\mathrm{AH}$, Kraft $\mathrm{KH}$, Boneta $\mathrm{O}$, Moon RE, et al. Hyperbaric oxygen treatment and bisphosphonateinduced osteonecrosis of the jaw: a case series. J Oral Maxillofac Surg 2007:65:1321-7.

27. Nastro E, Musolino C, Allegra A, Oteri G, Cicciù M, Alonci A, et al. Bisphosphonate associated osteonecrosis of the jaw in patients with multiple myeloma and breast cancer. Acta Haematol 2007;117:181-7.

28. O'Ryan FS, Khoury S, Liao W, Han MM, Hui RL, Baer D, et al. Intravenous bisphosphonate-related osteonecrosis of the jaw: bone scintigraphy as an early indicator. J Oral Maxillofac Surg 2009;67:1363-72.

29. Ma YL, Bryant HU, Zeng Q, Schmidt A, Hoover J, Cole HW, et al. New bone formation with e (human parathyroid hormone-(1-34)) is not retarded by long-term pretreatment with alendronate, estrogen, or raloxifene in ovariectomized rats. Endocrinology 2008;144:2008-15.

30. Cheung A, Seeman E. Teriparatid therapy for alendronate-associated osteonecrosis of the jaw. N Engl J Med 2010;363:2473-4.

31. Lau AN, Adachi JD. Resolution of osteonecrosis of the jaw after teriparatid [recombinant human $\mathrm{PTH}-(1-34)$ ] therapy. J Rheumato 2009;36:1835-7.

32. Harper RP, Fung E. Resolution of bisphosphonate-associated osteonecrosis of the mandible: possible application for intermittent lowdose parathyroid hormone [rhPTH (1-34)]. J Oral Maxillofac Surg 2007;65:573-80.

33. Bashutski JD, Eber RM, Kinney JS, Benavides E, Maitra S, Braun $\mathrm{TM}$, et al. Teriparatid and osseous regeneration in the oral cavity. $\mathrm{N}$ Engl J Med 2010;363:2396-405.

34. Miyauchi $A$, Matsumoto $T$, Shigeta $H$, Tsujimoto $M$, Thiebaud $D, N a$ kamura $T$. Effect of teriparatide on bone mineral density and biochemi- cal markers in Japanese women with postmenopausal osteoporosis: a 6 month dose response study. J Bone Miner Metab 2008;26:624-34

35. Sethi BK, Chadha M, Modi KD, Kumar KM, Mehrotra R, Sriram U. Efficacy of teriparatid in increasing bone mineral density in postmenopausal women with osteoporosis--an Indian experience. J Assoc Physicians India 2008:56:418-24

36. Anastasilakis AD, Goulis DG, Polyzos SA, Gerou S, Koukoulis GN, Efstathiadou Z, et al. Head-to-head comparison of risedronate vs. teriparatid on bone turnover markers in women with postmenopausal osteoporosis: a randomised trial. Int J Clin Pract 2008;62:919-24.

37. Okimoto N, Tsurukami H, Okazaki, Nishida S, Sakai A, Ohnishi H, et al. Effects of a weekly injection of human parathyroid hormone (1-34) and withdrawal on bone mass, strength, and turnover in mature ovariectomized rats. Bone 1998;22:523-31.

38. Kneissel M, Boyde A, Gasser JA. Bone tissue and its mineralization in aged estrogen-depleted rats after long-term intermittent treatment with parathyroid hormone (PTH) analog SDZ PTS 893 or human PTH (1-34). Bone 2001;28:237-50.

39. Pleiner-Duxneuner J, Zwettler E, Paschalis E, Roschger P, Nell-Duxneuner V, Klaushofer K. Treatment of osteoporosis with parathyroid hormone and teriparatide. Calcif Tissue Int 2009;84:159-70.

40. Girotra M, Rubin MR, Bilezikian JP. The use of parathyroid hormone in the treatment of osteoporosis. Rev Endocr Metab Disord 2006;7:11321.

\section{Teriparatide [parathyroid hormone (1-34)] and dentistry}

\section{Abstract}

Teriparatide is a new synthetic parathyroid hormone recently used with a purpose to improve the thickness and the quality of bone. Parathyroid hormone regulates the metabolism of calcium and phosphate and is responsible for bone formation. Teriparatide is a new antiosteoporosis drug and is known to prevent bone resorption in cases where mineral density is low or the quality of bone is inferior. Unlike other antiresorptive agents it possesses an anabolic effect on bone. In its mechanism of action, when bone resorption starts with osteoclast stimulation, osteoblasts are stimulated at the same time, resulting in the aforementioned anabolic effect. This effect has tempted researches to use this agent in cases of biphosphonate related osteonecrosis and periodontal bone defects. Research reveals no serious clinical side effects associated with this agent; however, a risk of osteosarcoma due to its anabolic effect on bone should be considered. Yet, no case of osteosarcoma related to the teriparatide use has been reported so far. In the literature, there exists only few case reports that has used teriparatide. Prospective randomized studies are needed to evaluate the long-term effectiveness of this drug.

KEYWORDS: Bisphosphonate-associated osteonecrosis of the jaw; osteoporosis; parathyroid hormone; teriparatide 